\title{
The Estimation of Glucose-Containing Substances in Micro- Organisms from the Rumen of the Sheep
}

\author{
By P. J. HEALD \\ Rowett Research Institute, Bucksburn, Aberdeenshire
}

(Received 17 August 1950)

Before studying glucose-containing substances in the micro-organisms from the rumen of sheep fed on hay, it was necessary to develop a method of estimation specific for glucose. Methods for the estimation of reducing sugars depend largely either on direct determinations of the reducing values of solutions or on such determinations before and after treatment of the solutions with bacteria or yeasts specifically fermenting single sugars or a group of sugars. Since such values are usually expressed in terms of an arbitrarily chosen sugar, the errors resulting when mixtures of reducing sugars are present, or when a large amount of non-sugar reducing material is present, can be considerable. In addition, the interpretation of the value of the non-sugar reducing materials is rendered difficult because different values are obtained depending on the method of estimation employed.

The procedure which has been devised involves quantitative paper-partition chromatography (Flood, Hirst \& Jones, 1947) of hydrolysates of the rumen microorganisms. The results of this method have been compared with the loss in reducing substances in the hydrolysate after fermentation with baker's yeast (The United Yeast Co. Ltd. (D.C.L.), King Street, Aberdeen).

\section{EXPERIMENTAL AND RESULTS}

\section{Paper chromatographic method}

Apparatus. All-glass tanks and troughs were used, since quantitative recovery of glucose was not obtained with a stainless steel trough. The paper used was Whatman no. 54 , since on this paper the sugars are maintained as compact 'spots' and a more regular solvent front is obtained than with the coarser-fibred Whatman no. I paper.

Since complete extraction was not always obtained by using the extractor originally described by Flood et al. (1947) the all-glass extractor shown in Fig. I was devised. This type of extractor was found highly satisfactory. It permits total extraction in 20-30 min.

Chromatographic technique. The method used was essentially that described by Flood et al. (x947) as modified by Jermyn \& Isherwood (1949). A horizontal micro-capillary burette was used to apply the solution to the paper.

The sheets were run in a mixture containing $n$-butanol (40 parts), acetic acid (Io parts) and water (50 parts) for $24-48 \mathrm{hr}$. (Partridge, 1948), after which they were dried at I0 ${ }^{\circ}$ and the 'side-strips' removed and sprayed as described by Flood et al. (1947). In all these operations forceps were used to handle the cut paper strips. The sections 
of the paper horizontally adjacent to the located glucose spots were then removed, rolled with forceps and placed in the cup of the extractor. The extractor was fitted to a ground$\mathrm{j}$ oint boiling tube, and ro $\mathrm{ml}$. distilled water were delivered through the paper roll into the tube. The tube and extractor were then fitted to a re-

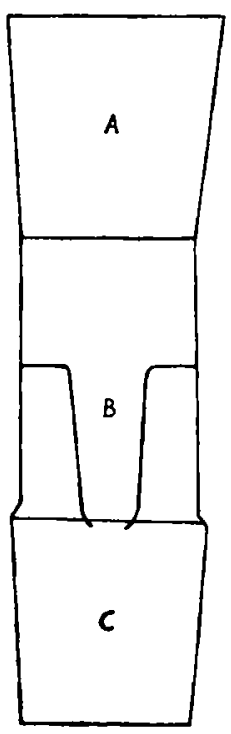

Fig. 1. Paper-strip extraction apparatus. $A$ and $C$ are groundglass joints. $B$ is a glass cup to contain the paper strip. The cut paper strip is rolled and the roll placed in the inner cup, $B$. The extractor is connected to a condenser at joint $A$ and to the extraction tube, containing water, at $C$. flux condenser and heated so that the condensate bubbled about the paper roll. At intervals the heater was removed and the condensate allowed to drain into the tube. The tubes were cooled, $3 \mathrm{ml}$. water added through the paper roll and the extractors removed. The reducing sugars in the extracts were estimated by the method of Hagedorn \& Jensen (1923) using sodium starch glycollate as the indicator in the titration (Peat, Bourne \& Thrower, 1947).

Before each estimation the extractors and tubes were cleaned in hot chromic-sulphuric acid to prevent interference from grease. With this procedure, the blank values of the paper strips were $\mathrm{r} \cdot 85 \pm 0.04 \mathrm{ml} .0 .005 \mathrm{~N}$ sodium thiosulphate, and the recovery of glucose added to the strips ranged from 94 to $100 \%$.

Preparation of hydrolysates for chromatography. Either freshly centrifuged rumen micro-organisms or acetone powders were used. The acetone powders were prepared by blowing a thick suspension of the micro-organisms from a pipette into $10 \mathrm{vol}$. ice-cold acetone, the mixture being stirred rapidly during this addition. The suspension was immediately filtered, washed with a little ether, and dried in vacuo at room temperature. The powders were hydrolysed in sealed tubes with $\mathrm{N}-\mathrm{HCl}$ at $100^{\circ}$ for $3 \mathrm{hr}$. The seals were then broken and the contents of the tubes were adjusted (Congo red) to $\mathrm{pH}_{4.5}$ with silver carbonate. After centrifuging, portions of the supernatant liquids were evaporated to dryness at room temperature over phosphorus pentoxide under reduced pressure. The residues were taken up in either 0.5 or $1.0 \mathrm{ml}$. distilled water and centrifuged to remove solid particles. The clear supernatant liquids were added to the paper from a micro-burette. The concentrations of these solutions were adjusted so that about 200-250 $\mu \mathrm{g}$. glucose were added to the paper.

Notes on the procedure. The blank strips were cut from above the point of application of the solution to eliminate any possible interference from non-sugar contaminants. 'The hydrolysates of the micro-organisms contained many substances that fluoresced under an ultraviolet lamp. A preliminary examination of the dried, developed sheet indicated the shape of the solvent 'front' which had passed out of the paper and facilitated the cutting of the glucose-containing sections.

Phenol, even in minute amounts, prevents the estimation of reducing sugars by the Hagedorn-Jensen method, because on addition of the zinc sulphate a brown colour develops and the end-point may last over the addition of $0.5 \mathrm{ml}$. thiosulphate. 'The 
'blank' values in such instances were raised to $\times 150 \mathrm{ml}$. thiosulphate. When for any reason phenol had been used, all the apparatus and the drying oven were washed with ethanol before further quantitative work was carried out.

\section{Fermentation method}

The method used was similar to that described by Mann (1946), with the following slight changes in procedure. The yeast (fresh baker's yeast) was twice washed in the centrifuge with $0^{\circ}$ I M-phosphate buffer $(\mathrm{pH} \mathrm{6.8)}$ and resuspended in buffer so that $2 \mathrm{ml}$. suspension contained $0.7 \mathrm{~g}$. yeast. This volume was added to $5 \mathrm{ml}$. of a suitably diluted sample of neutralized hydrolysate and the whole incubated at $30^{\circ}$ for I hr. After centrifuging, a portion of the supernatant liquid was removed for estimation of reducing substances by the Hagedorn-Jensen method. The difference between this value and the value obtained for the unfermented hydrolysate was termed 'fermentable reducing substances'.

\section{Qualitative analysis of sugars in hydrolysates of rumen micro-organisms}

In all these experiments acetone powders of the rumen micro-organisms were hydrolysed as already described, and the hydrolysates were passed first over 'ZeoKarb 215' (Permutit Co. London) and then over 'Deacidite $\beta$ ' (Permutit Co. London) (Partridge, 1948). The solutions were concentrated and subjected to paper chromatography in phenol, collidine, and the mixture of $n$-butanol, acetic acid and water. Glucose was shown to be present as the major component together with some arabinose, xylose, ribose and rhamnose. The ribose presumably arose from nucleic acid. The other pentoses were probably derived from small plant particles which could not be easily removed in the preparation of the acetone powders. No other sugars were detected.

Table 1. Effect of casein on recovery of glucose after hydrolysis with $\mathrm{N}-\mathrm{HCl}$

\begin{tabular}{|c|c|c|c|c|c|}
\hline \multirow[b]{2}{*}{ Substance tested } & \multirow[b]{2}{*}{$\begin{array}{l}\text { Casein } \\
\text { (mg.) }\end{array}$} & \multicolumn{4}{|c|}{ Glucose } \\
\hline & & $\begin{array}{l}\text { Before } \\
\text { hydrolysis } \\
\text { (mg.) }\end{array}$ & $\begin{array}{c}\text { After } \\
\text { hydrolysis } \\
\text { (mg.) }\end{array}$ & $\begin{array}{l}\text { Corrected } \\
\text { for casein } \\
\text { (mg.) }\end{array}$ & $\begin{array}{l}\text { Loss } \\
\text { (mg.) }\end{array}$ \\
\hline Glucose with casein & $145 \cdot 3$ & $24^{\circ} 0$ & $29 \cdot 0$ & $22 \cdot 0$ & $2 \cdot 0$ \\
\hline Glucose with casein & $127^{\circ} 0$ & $24^{\circ} 0$ & $28 \cdot 4$ & $2 I \cdot 9$ & $2 \cdot 1$ \\
\hline Casein & $139 \cdot 9$ & 0 & $7 \cdot 0$ & 一 & 一 \\
\hline Casein & $165 \cdot 3$ & - & $7 \cdot 7$ & 一 & 一 \\
\hline Glucose & - & $24 \cdot 0$ & $23 \cdot 3$ & - & 0.7 \\
\hline Glucose & - & $24^{\circ} 0$ & $23 \cdot 6$ & - & 0.4 \\
\hline
\end{tabular}

The production of reducing substances from the acetone powders appeared to be greatest after hydrolysis for $3 \mathrm{hr}$. Thus in one experiment the production amounted to $10.6 \%$ after $3 \mathrm{hr}$. as compared with $9.2 \%$ after both $\mathrm{I}$ and $2 \mathrm{hr}$. and $10.0 \%$ after $4 \mathrm{hr}$. The results of tests in which glucose was subjected to the hydrolysis treatment for 3 or $4 \mathrm{hr}$. alone and also in the presence of casein are shown Table I, and results for the recovery of glucose added to the acetone powders before hydrolysis are given in 'Table 2. Glucose recovery in the acetone powders appeared to be similar to that 
Table 2. Recovery of glucose after hydrolysis in the presence of acetone powders of micro-organisms

$\begin{array}{ccccc}\text { Acetone } \\ \begin{array}{c}\text { powder } \\ \text { (mg.) }\end{array} & \begin{array}{c}\text { Added } \\ \text { (mg.) }\end{array} & \overbrace{\begin{array}{c}3 \mathrm{hr} . \\ (\mathrm{mg} .)\end{array}}^{\text {Recovered after hydrolysing for }} & \begin{array}{c}4 \mathrm{hr} . \\ (\mathrm{mg})\end{array} & \begin{array}{c}\text { Loss } \\ (\mathrm{mg} .)\end{array} \\ 89.0 & 4.4 & 4.2 & - & 0.2 \\ 89.0 & 4.4 & 4.1 & - & 0.3 \\ 89.0 & 4.4 & 4.3 & - & 0.1 \\ - & 4.4 & 4.3 & - & 0.1 \\ 45.0 & 17.1 & - & 15.3 & 1.8 \\ 68.5 & 17.1 & - & 16.0 & 1.1 \\ - & 17.1 & - & 16.4 & 0.7\end{array}$

obtained in the presence of casein. It would seem, therefore, that the loss of glucose was likely to be due mainly to the presence of protein in the micro-organisms.

Attempted chromatography of the hydrolysate. Early attempts to obtain chromatograms were made by concentrating the supernatant liquids from the centrifuged hydrolysates in vacuo over phosphorus pentoxide and potassium hydroxide. The dark brown residues amounted to $60 \%$ of the dry weight of the powders, and chromatograms obtained from solutions of these showed gross contamination. The use of ion exchange resins 'Zeo-Karb 2 I 5 ' and 'Deacidite $\beta$ ', though leading to well-defined chromatograms, presented considerable technical difficulty for routine work and so was abandoned. In an attempt to overcome this difficulty various methods were examined. These consisted of $(a)$ the possible extraction of the glucose-containing substances prior to hydrolysis, and $(b)$ other methods of purification of the hydrolysates.

Extraction experiments. Since it has been postulated that the major glucose-containing substances in rumen micro-organisms resemble starch (Baker \& Harriss, 1947-8), starch (A. R., British Drug Houses Ltd.) was selected as a reference substance. Schoch \& Jensen (1940) have shown that starch solutions buffered between pH 5.9 and 6.3 may be autoclaved for relatively long periods without a change in the 'alkali number', which is said to be a more sensitive criterion of chemical change in the starch molecule than the reducing value as estimated by the copper or ferricyanide reduction-values (Farley \& Hixon, I94I; Schoch, 1945). When this treatment was applied to starch solutions buffered to $\mathrm{pH} 5.9$ at room temperature with Sørensen's citrate buffer, in $3 \mathrm{hr}$. at $100^{\circ}$ there was a loss of about $10 \%$ in the reducing value of the starch subsequently hydrolysed and precipitated (see Table 3). A similar treatment of acetone powders showed that not all the reducing substances were extracted (see Table 4).

It was thought that, if the total reducing values determined were due partly to substances other than glucose, the citrate treatment might not be extracting these substances. In this case there would be a difference in reducing values between the hydrolysed extracts and the unextracted sediments. The reducing substances fermentable by yeast in both the hydrolysed extracts and the unextracted sediment were estimated. The results, presented in Table 5, showed that there were still some fermentable reducing substances in the sediment not extracted with citrate buffer.

This approach was therefore abandoned. 
Table 3. Loss of starch from solutions buffered with citrate after hydrolysis

\begin{tabular}{|c|c|c|c|c|c|c|c|}
\hline \multirow[b]{2}{*}{ Solution } & \multirow[b]{2}{*}{ Treatment } & \multirow[b]{2}{*}{$\begin{array}{c}\text { First } \\
\text { pre- } \\
\text { cipitate } \\
\text { (mg.) }\end{array}$} & \multirow[b]{2}{*}{$\begin{array}{l}\text { Second } \\
\text { pre- } \\
\text { cipitate† } \\
\text { (mg.) }\end{array}$} & \multirow[b]{2}{*}{$\begin{array}{l}\text { Difference } \\
\text { (mg.) }\end{array}$} & \multirow[b]{2}{*}{$\begin{array}{c}\text { Difference } \\
(\%)\end{array}$} & \multicolumn{2}{|c|}{$\begin{array}{l}\text { Glucose after } \\
\text { hydrolysis }\end{array}$} \\
\hline & & & & & & (mg.) & $\begin{array}{c}\text { As } \\
\text { percentage } \\
\text { second } \\
\text { pre- } \\
\text { cipitate }\end{array}$ \\
\hline Starch and buffer & $\begin{array}{l}\text { Hydrolysis for } \\
3 \mathrm{hr} \text {. at } 100^{\circ} \\
\text { before precipita- } \\
\text { tion }\end{array}$ & $\begin{array}{r}19.6 \\
19.4\end{array}$ & $\begin{array}{l}15.8 \\
15.8\end{array}$ & $\begin{array}{l}-3 \cdot 7 \\
-3 \cdot 5\end{array}$ & $=$ & $\begin{array}{l}14 \cdot 2 \\
14 \cdot 2\end{array}$ & $\begin{array}{l}89 \cdot 6 \\
90 \cdot 2\end{array}$ \\
\hline Starch & $\begin{array}{l}\text { Precipitation } \\
\text { with } 5 \text { vol. } \\
\text { ethanol }\end{array}$ & $\begin{array}{l}16 \cdot 6 \\
16 \cdot 2\end{array}$ & $\begin{array}{l}16 \cdot 0 \\
15 \cdot 5\end{array}$ & $\begin{array}{l}-0.6 \\
-0.6\end{array}$ & $\begin{array}{l}-3.78 \\
-4.08\end{array}$ & $\begin{array}{l}15 \cdot 8 \\
15.4\end{array}$ & $\begin{array}{l}98 \cdot 8 \\
99 \cdot 5\end{array}$ \\
\hline $\begin{array}{l}\text { Starch with } \\
\mathrm{N}-\mathrm{HCl}\end{array}$ & $\begin{array}{l}\text { Hydrolysis for } \\
3 \mathrm{hr} \text {. at } 100^{\circ}\end{array}$ & $\begin{array}{l}- \\
-\end{array}$ & - & - & 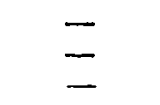 & $\begin{array}{l}16 \cdot 6 \\
16 \cdot 4 \\
16 \cdot 4\end{array}$ & - \\
\hline
\end{tabular}

- All weights are given as glucose equivalents of the starch weighed, i.e. weight $+10 \%$.

+ The starch was precipitated twice to remove traces of sodium citrate contained in the first precipitate.

Table 4. Extraction of reducing substances from acetone powders of microorganisms by hydrolysis in citrate buffer

Reducing substances extracted after

$$
\begin{aligned}
& \text { Powder } \\
& \text { taken } \\
& \text { (mg.) } \\
& 18 \mathrm{x} \cdot 9 \\
& 199^{\circ} 5
\end{aligned}
$$

\begin{tabular}{|c|c|c|c|c|c|c|}
\hline \multirow[b]{2}{*}{$\begin{array}{l}\text { Powder } \\
\text { taken } \\
\text { (mg.) }\end{array}$} & \multirow[b]{2}{*}{$\begin{array}{l}\text { Hydrolysis } \\
\text { in }\end{array}$} & \multicolumn{5}{|c|}{ Reducing substances } \\
\hline & & $\begin{array}{c}\text { Before } \\
\text { fermeritation } \\
\text { (mg.) }\end{array}$ & $\begin{array}{c}\text { After } \\
\text { fermentation } \\
\text { (mg.) }\end{array}$ & $\begin{array}{l}\text { Difference } \\
\text { (mg.) }\end{array}$ & $\begin{array}{c}\text { Ferment- } \\
\text { able } \\
(\%)\end{array}$ & $\begin{array}{c}\text { Non- } \\
\text { fermentable } \\
(\%)\end{array}$ \\
\hline $\begin{array}{l}206 \cdot 0 \\
208 \cdot 8 \\
205 \cdot 3\end{array}$ & $\begin{array}{l}\mathrm{N}-\mathrm{HCl} \text { for } 3 \mathrm{hr} . \\
\text { at } 100^{\circ}\end{array}$ & $\begin{array}{l}26 \cdot 0 \\
24 \cdot 9 \\
25 \cdot 3\end{array}$ & $\begin{array}{l}18 \cdot 6 \\
18 \cdot 3 \\
18 \cdot 1\end{array}$ & $\begin{array}{l}-7 \cdot 4 \\
-6 \cdot 6 \\
-7 \cdot 2\end{array}$ & $\begin{array}{l}3 \cdot 6 \\
3 \cdot 2 \\
3 \cdot 5\end{array}$ & $\begin{array}{l}9 \cdot 0 \\
8 \cdot 8 \\
8 \cdot 8\end{array}$ \\
\hline $\begin{array}{l}206 \cdot 3 \\
177 \cdot 0\end{array}$ & Citrate buffer & $\begin{array}{l}10.1 \\
10.0\end{array}$ & $\begin{array}{l}7 \cdot 6 \\
7 \cdot 2\end{array}$ & $\begin{array}{l}-2.5 \\
-2.8\end{array}$ & $\begin{array}{l}1 \cdot 2 \\
1 \cdot 6\end{array}$ & $\begin{array}{l}3.7 \\
4.1\end{array}$ \\
\hline
\end{tabular}

$\begin{gathered}\text { Hydrolysis } \\ \text { in }\end{gathered}$
$\mathrm{N}-\mathrm{HCl}$

Citrate buffer

$\mathrm{N}-\mathrm{HCl}$

Citrate buffer hydrolysis for

$\begin{array}{cc}\begin{array}{c}3 \mathrm{hr} . \\ (\%)\end{array} & 6 \mathrm{hr} . \\ 12 \cdot 0 & - \\ 12 \cdot 3 & - \\ 6.6 & - \\ 6.5 & - \\ - & 12 \cdot 6 \\ - & 12.5 \\ - & 7 \cdot 6 \\ & 7.1\end{array}$

Table 5. Fermentable, non-fermentable and total reducing substances in citrate extracts of acetone powders of micro-organisms

Purification of the acid hydrolysates. It was found that if the acid hydrolysates were neutralized to Congo red with silver carbonate, clear, almost colourless supernatant 
liquids could be obtained on centrifuging the mixtures. These could be concentrated under reduced pressure, and the residues, when dissolved in a small volume of water and spotted on to paper, gave well-defined chromatograms though they were not completely free from contamination. Glucose was recovered from acid solution after neutralization with silver carbonate and chromatography to the extent of $94 \%$ with a range from 87 to $99 \%$ (see Table 6), and the reference starch similarly treated after

Table 6. Recovery of glucose by paper chromatography from acid solution after treatment with silver carbonate

\begin{tabular}{|c|c|c|c|c|}
\hline \multirow{3}{*}{$\begin{array}{c}\text { Solution } \\
\text { taken } \\
(\mu 1 .)\end{array}$} & \multicolumn{2}{|c|}{ Glucose } & \multirow{2}{*}{\multicolumn{2}{|c|}{ Loss }} \\
\hline & \multirow{2}{*}{$\begin{array}{c}\text { Taken } \\
\text { ( } \mu g .)\end{array}$} & \multirow{2}{*}{$\underset{(\mu \mathrm{g} .)}{\text { Recovered }}$} & & \\
\hline & & & $\mu g$. & $\%$ \\
\hline 35.5 & 236 & 222 & $x 4$ & 5.9 \\
\hline $47^{\circ} \circ$ & 312 & 272 & 40 & 12.8 \\
\hline $42 \cdot 5$ & 282 & 259 & 23 & $8 \cdot 1$ \\
\hline 28.5 & 190 & 184 & 6 & $3 \cdot 2$ \\
\hline 33.5 & 223 & 220 & 3 & $1 \cdot 3$ \\
\hline $44^{\circ} 0$ & 292 & $27 \mathrm{I}$ & $2 I$ & $7 \cdot 2$ \\
\hline 35.5 & 236 & $23 I$ & 5 & $2 \cdot I$ \\
\hline 40.0 & 266 & 246 & 20 & $7 \cdot 7$ \\
\hline
\end{tabular}

hydrolysis was recovered to a somewhat similar degree (see 'Table 10). Although these values appear to vary appreciably when calculated as a percentage of the amount added to the chromatogram, it will be seen from Table 7 that the variation in the actual content of material was relatively small. Since the percentage error would increase as the quantity of glucose added was decreased, quantities of $250-300 \mu \mathrm{g}$. glucose were added to the paper.

Table 7. Recovery of starch (as glucose) after hydrolysis and paper chromatography

\begin{tabular}{|c|c|}
\hline \multicolumn{2}{|c|}{ Starch } \\
\hline $\begin{array}{c}\text { Taken } \\
\text { (mg./ml.) }\end{array}$ & $\begin{array}{l}\text { Recovered } \\
\text { (mg./ml.) }\end{array}$ \\
\hline 5.04 & $4 \cdot 56$ \\
\hline $\begin{array}{l}5.05 \\
5.01\end{array}$ & $\begin{array}{l}4.40 \\
4.80\end{array}$ \\
\hline
\end{tabular}

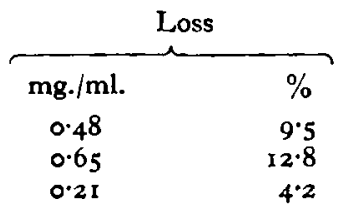

Experiments on the fermentable fraction. As noted on p. 79, the hydrolysates contained a large percentage of a non-fermentable reducing substance. It was thought that this might be produced during hydrolysis (cf. Sattler, 1948). An estimation of the fermentable reducing substances produced after hydrolysis for $\mathrm{I}$ and $3 \mathrm{hr}$. (Table 8) showed that this was not likely to be so. The decrease in the percentage of fermentable reducing substances between $\mathrm{I}$ and $3 \mathrm{hr}$. hydrolysis was small but definite, about $0.25 \mathrm{mg}$. glucose, and was of the same order as the loss of glucose shown in Table 2. The increase in the percentage of non-fermentable reducing substances is considered to have been duc to a further hydrolysis of those substances that gave rise to them in the sediment.

In an attempt to obtain a more accurate assessment of the fermentable fraction, 
Table 8. Fermentable, non-fermentable and total reducing substances in hydrolysates of acetone powders of rumen micro-organisms

\begin{tabular}{|c|c|c|c|c|c|c|c|}
\hline \multirow[b]{2}{*}{$\begin{array}{l}\text { Powder } \\
\text { taken } \\
\text { (mg.) }\end{array}$} & \multirow[b]{2}{*}{$\begin{array}{l}\text { Hydrolysis } \\
\text { in } \mathrm{N}-\mathrm{HCl} \\
\text { for }\end{array}$} & \multicolumn{3}{|c|}{ Glucose } & \multicolumn{3}{|c|}{ Reducing substances } \\
\hline & & $\begin{array}{c}\text { Before } \\
\text { fermentation } \\
\text { (mg.) }\end{array}$ & $\begin{array}{c}\text { After } \\
\text { fermentation } \\
\text { (mg.) }\end{array}$ & $\begin{array}{l}\text { Difference } \\
\text { (mg.) }\end{array}$ & $\begin{array}{c}\text { Fermentable } \\
(\%)\end{array}$ & $\begin{array}{c}\text { Non- } \\
\text { fermentable } \\
(\%)\end{array}$ & $\begin{array}{l}\text { Total } \\
(\%)\end{array}$ \\
\hline 2047 & $1 \mathrm{hr}$. & $25 \cdot 3$ & $\begin{array}{l}15.7 \\
15.8\end{array}$ & $-9 \cdot 6$ & $\begin{array}{r}4.70 \\
4.70\end{array}$ & 7.65 & $\begin{array}{r}12 \cdot 35 \\
12 \cdot 35\end{array}$ \\
\hline $\begin{array}{l}204: 3 \\
204 \cdot 0\end{array}$ & $\begin{array}{l}\text { I hr. } \\
3 \mathrm{hr} \text {. }\end{array}$ & $\begin{array}{l}25.3 \\
26.8\end{array}$ & $\begin{array}{l}15.8 \\
17.7\end{array}$ & $\begin{array}{l}-9.5 \\
-9.1\end{array}$ & $\begin{array}{l}4 \cdot 70 \\
4 \cdot 45\end{array}$ & $\begin{array}{l}7.65 \\
8.67\end{array}$ & $\begin{array}{r}12 \cdot 35 \\
13 \cdot 12\end{array}$ \\
\hline $208 \cdot 3$ & $3 \mathrm{hr}$. & $26 \cdot 5$ & 17.4 & $-9 \cdot I$ & 4.37 & $8 \cdot 32$ & 12.69 \\
\hline
\end{tabular}

estimations of reducing substances were carried out with both the Somogyi (1945) micro-sugar reagent and the Hagedorn-Jensen method. A heating period of $20 \mathrm{~min}$. was adopted for the Somogyi reagent to allow for the estimation of any xylose that might be present. The results are presented in Table 9 and showed that the Somogyi method gave a higher result for fermentable reducing substances and a lower result for the non-fermentable substances than the Hagedorn-Jensen method.

Table 9. Fermentable and non-fermentable reducing substances in acetone powders of rumen micro-organisms estimated by two methods

\begin{tabular}{|c|c|c|c|c|c|c|}
\hline \multirow[b]{3}{*}{$\begin{array}{l}\text { Powder } \\
\text { taken } \\
\text { (mg.) }\end{array}$} & \multicolumn{6}{|c|}{ Reducing substances } \\
\hline & \multicolumn{2}{|c|}{ Fermentable } & \multicolumn{2}{|c|}{ Non-fermentable } & \multicolumn{2}{|c|}{ Total } \\
\hline & $\begin{array}{c}\text { Hagedorn- } \\
\text { Jensen } \\
(\%)\end{array}$ & $\begin{array}{c}\text { Somogyi } \\
(\%)\end{array}$ & $\begin{array}{l}\text { Hagedorn- } \\
\text { Jensen } \\
(\%)\end{array}$ & $\begin{array}{c}\text { Somogyi } \\
(\%)\end{array}$ & $\begin{array}{c}\text { Hagedorn- } \\
\text { Jensen } \\
(\%)\end{array}$ & $\begin{array}{c}\text { Somogyi } \\
(\%)\end{array}$ \\
\hline $208 \cdot 9$ & $12 \cdot 8$ & $14: 4$ & $6 \cdot 3$ & $3 \cdot 6$ & Ig. I & $18 \cdot 3$ \\
\hline 204.8 & 12.6 & 14.8 & $5 \cdot 2$ & $3 \cdot 1$ & $\times 7.8$ & $17 \cdot 8$ \\
\hline $217 \cdot 2$ & $2 \cdot 0$ & $4 \cdot 1$ & $7 \cdot 7$ & 2.6 & $9 \cdot 7$ & 6.7 \\
\hline $203 \cdot 3$ & $2 \cdot 1$ & 3.9 & 7.7 & 3.3 & $9 \cdot 8$ & $7^{\cdot 2}$ \\
\hline $204 \cdot 2$ & $1 \cdot 5$ & $3 \cdot 3$ & $8 \cdot 0$ & 3.2 & 9.5 & $6 \cdot 5$ \\
\hline
\end{tabular}

Chromatograms were obtained from hydrolysates both before and after fermentation. The solutions were passed through 'Zeo-Karb 215' and 'Deacidite $\beta$ ' and the effluents evaporated and extracted with $95 \%$ ethanol. After removal of the ethanol the residues were dissolved in O.r ml. water, spotted on to paper and developed in the $n$-butanolacetic acid-water mixture for $48 \mathrm{hr}$. Glucose was included as a reference sugar. On drying and spraying with silver nitrate (Partridge, 1948), it was seen that glucose had been removed during fermentation, but xylose, arabinose, ribose, and rhamnose appeared to be unaffected.

A comparison of the results for fermentable reducing substances, as estimated with the Hagedorn-Jensen method, with those for glucose as estimated by the chromatographic method is presented in Table ro. The samples of sediments used were prepared from rumen contents of sheep collected at different times after feeding. The close agreement between these values in Table 10 , taken in conjunction with the results in Table 9, suggests that the results given by the Hagedorn-Jensen method for glucose are more accurate than those given by the Somogyi method. 
Table 10. Comparison of glucose determined chromatographically with fermentable reducing substance determined by the Hagedorn-fensen method in three different samples of acetone powders of rumen micro-organisms

$\begin{array}{ccc}\begin{array}{c}\text { Sample } \\ \text { no. }\end{array} & \begin{array}{c}\text { Glucose } \\ (\%)\end{array} & \begin{array}{c}\text { Fermentable } \\ \text { reducing substance }\end{array} \\ \text { I } & 5.51 & (\%) \\ 2 & 4.64 & 6.61 \\ 3 & 3.58 & 4.12 \\ & 3.15\end{array}$

Each estimation in the second column is an average for four chromatograms. The values in the third column are averages of duplicates.

\section{DISCUSSION}

The first important point to observe is that no explanation can be offered for the apparent loss of starch when this is heated with citrate buffer.

A second point concerns the discrepancy between the values obtained when the percentage of fermentable and non-fermentable reducing sugars was estimated by both the Hagedorn-Jensen and Somogyi methods.

It has long been realized that in the presence of a large amount of protein the estimation of a polysaccharide presents considerable difficulties. These have been discussed by Dagley \& Dawes (1949) who hydrolysed a strain of Escherichia coli (Bacterium coli) with sulphuric acid and estimated by the Hagedorn-Jensen and Somogyi methods the reducing substances formed. They compared the results thus obtained with those obtained by applying the Sahyun (193I) method for glycogen to the bacteria (cf. Dawson \& Happold, 1943). The Hagedorn-Jensen method gave a high result and the Sahyun method a low result as compared with the Somogyi method. Dagley \& Dawes (1949) assume that the last method gives the more correct result. The experiments reported in this paper (see Tables 8 and 9) would suggest that, with some bacteria, even the Somogyi method can give high results. It seems clear that, unless the carbohydrate can be unequivocally identified and separated, the usual procedures cannot fail to give confusing results. It is suggested that since the chromatographic procedure separates the required carbohydrate, in this case glucose, from the others present and from non-sugar reducing substances, this condition is fulfilled. In such a case one of the several methods available for the micro-estimation of carbohydrates can be used.

The fraction designated 'non-fermentable reducing substances' presents a problem that has not yet been solved. It does not seem reasonable to think that these substances might consist solely of carbohydrates, since only small quantities of the other sugars described could be detected on the chromatogram. In addition it was found (Heald, unpublished observations) that in fractions of micro-organisms free from plant material, the percentage of non-fermentable reducing substances was still $8-9 \%$. It is suggested that though these substances arise during the hydrolysis procedure they are not artifacts arising by reason of the method of estimation employed. In addition it is suggested that the fraction is a composite fraction arising from several substances. The nature of these substances remains to be determined. 


\section{SUMMARY}

1. A paper-partition chromatographic method for the estimation of glucose in hydrolysates of rumen micro-organisms has been developed. The micro-organisms are hydrolysed in hydrochloric acid, the chloride-free solutions are concentrated and the glucose is separated from other substances by paper chromatography. Glucose is estimated by the Hagedorn-Jensen method. Glucose recovery by this method averaged $94 \%$ and ranged from 87 to $99 \%$.

2. Non-fermentable reducing substances were apparently present in large quantities in the hydrolysates of rumen micro-organisms.

3. It was not possible to extract the glucose-containing material from the microorganisms by means of a citrate buffer.

4. In addition to glucose, the preparations of micro-organisms contained arabinose, xylose, ribose and rhamnose in small quantities.

The author wishes to thank $\mathrm{Dr} \mathrm{J}$. Tosic for suggesting the problem and for his guidance and encouragement during the course of the work.

\section{REFERENCES}

Baker, F. \& Harriss, S. T. (1947-8). Nutr. Abstr. Rev. 17, 3.

Dagley, S. \& Dawes, E. A. (1949). Biochem. F. 45, 331.

Dawson, J. \& Happold, F. C. (1943). Biochem. F. 37, 389.

Farley, F. F. \& Hixon, R. M. (I94I). Industr. Engng Chem. (Anal. ed.), 13, 616.

Flood, A. E., Hirst, E. L. \& Jones, J. K. N. (1947). Nature, Lond., 160, 86.

Hagedorn, H. C. \& Jensen, N. B. (1923). Biochem. Z. 135, 46.

Jermyn, M. A. \& Isherwood, F. A. (1949). Biochem. Y. 44, 402.

Mann, T. (1946). Biochem. F. 40, 481 .

Partridge, S. M. (1948). Biochem. F. 42, 238.

Peat, S., Bourne, E. J. \& Thrower, R. D. (1947). Nature, Lond., r59, 810.

Sahyun, M. ( 1931). \%. biol. Chem. $93,227$.

Sattler, L. (1948). Adv. Carbohydrate Chem. 3, I 13.

Schoch, T. J. (1945). Adv. Carbohydrate Chem. 1, 247.

Schoch, T. J. \& Jensen, C. C. (1940). Industr. Engng Chem. (Anal. ed.), 12, 531.

Somogyi, M. (1945). F. biol. Chem. r60, 6r. 